\section{Think royalties, not caps}

Earlier this year, US Representative Bernard Sanders of Vermont introduced the Health Care Research and Development and Taxpayer Act, which resurrected and expanded the notion of putting price caps on drugs resulting from research initiated by federally funded institutions and universities. The thinking behind the bill is that US taxpayer-funded research should not be used to subsidize for-profit drug companies, and that US citizens should not be "double billed" for the end products of research-drugs-they have already contributed toward with tax dollars.

The act would prohibit any federally funded institution from granting exclusive research rights to any company until that company has agreed to enter into a cost-based reasonable pricing agreement. It would further require the government to put governmentfunded research up for competitive bidding, in which the winner will be the company that offers to charge the least amount for the drugs it makes, asks for the shortest period of drug exclusivity rights, and so forth.

It is difficult to imagine how such a bill would ever fly. One could beg the question altogether by arguing that federally funded research fuels most sectors of the US economy, but that gives short shrift to the fact that, in the US, health care research and public access to it is held in a much different light than, say, defense-related technology.

One alternative to the price cap solution-inherently a disincentive to research and development and a bureaucratic nightmare to establish and maintain-would be the creation of an incentive program of royalty payments like those drawn up between biotechnology and pharmaceutical companies. Companies that take federally fund- ed research-by whatever technology transfer route-into drug development would pay royalties to the federally funded institutions that initiated the research, based on how far that research takes them down the drug pipeline-from a look-see to product approval-thus ensuring a taxpayer "payment in kind." Although it would be difficult to assess the value of a particular piece of research's contribution to a drug's development, such is already the case with deals being made between biotechs and pharmas-deals that are based in part on data, and in part on negotiation and good faith-and where equitable arrangements do in the end get reached. And in the event that the research yields some utterly unpredictable financial windfall, so much the better for the intiating institutions.

Our suggestion of having companies "reimburse" taxpayers for federally funded research by paying research royalties does not address the thorny and difficult issue of how to make drugs and health care available and affordable for all citizens. Drug pricing is extremely complex and most players in the pharmaceutical industry-from health insurers to government regulators to drug companies--have been loathe to address in any systematic way, which is one reason why the idea of capping drug prices resurfaces every so often.

Price capping would create more problems than it would solve. A royalty incentive program would at least be one way for industry to nurture and sustain the basic research that is its own bread and butter on a regular basis, while giving taxpayers the accountability they deserve. We are also certain that more creative solutions to pricing issues and the problem of affordable pharmaceuticals would be forthcoming if the industry made it the priority it ought to be.

\title{
Structural genomics: Simply the next new thing- or is this it?
}

From its heady beginnings almost 20 years ago until now, biotechnology, like other marriages of science, technology and commerce, has thrived on the idea of the "next new thing." But unlike analogous combinations-the desktop computer industry, for example-the biotechnologies often give the appearance of moving on to the new thing before the old thing has had a chance to fully develop. Given the complexity of the latter, this is understandable. It is nonetheless remarkable that what is perhaps the earliest biotechnology joke, first heard in 1983-about the thrice-married virgin--remains wryly amusing even today. (Husbands number one and two passed away before the marriage could be consummated, and the third was a biotechnologist who sat on the edge of the bed every night and talked until dawn about how good it was going to be.) But it just may be that biotechnology's newest thing, structural genomics, will complete the union that biotechnology has, for all these years, been on the verge of achieving.

Structural genomics is the term given to the rapid generation of protein structures in the context of genome sequence data, using advanced crystallographic techniques in combination with computational and other mathematical approaches. Its working premise is that, since there are only a relatively small number-perhaps 5000 - of representative protein folding classes, by obtaining enough structures to populate each class sufficiently it will be possible to "thread" any new DNA sequence and quickly arrive at a highly accurate predicted protein structure. And as a result, in part, of what is already being regarded as a watershed conference held at the Argonne National Laboratory early this year, this seemingly perfectly matched partner to functional genomics (supplying the shapes to go with the targets), is rapidly emerging as biotech's next "technology suite." In this issue of Nature Biotechnology (p. 625), Terry Gaasterland, one of the coorganizers of the Argonne meeting, discusses the methods and ideas informing this approach, the range of potential applications it offers, and the formidable problems that will need to be solved before such applications are really forthcoming.

It has always been a guiding tenet of molecular biology that structure and function are intimately connected, much as the two strands of the DNA helix. Knowledge of either one may be extremely rewarding, but a knowledge of what the two together represent is truly powerful. 